\title{
Gut proteases target Yersinia invasin in vivo
}

\author{
Janja Trček, Marc F Oellerich, Katy Niedung, Frank Ebel, Sandra Freund and Konrad Trülzsch ${ }^{*}$
}

\begin{abstract}
Background: Yersinia enterocolitica is a common cause of food borne gastrointestinal disease. After oral uptake, yersiniae invade Peyer's patches of the distal ileum. This is accomplished by the binding of the Yersinia invasin to $\beta 1$ integrins on the apical surface of $M$ cells which overlie follicle associated lymphoid tissue. The gut represents a barrier that severely limits yersiniae from reaching deeper tissues such as Peyer's patches. We wondered if gut protease attack on invasion factors could contribute to the low number of yersiniae invading Peyer's patches.

Findings: Here we show that invasin is rapidly degraded in vivo by gut proteases in the mouse infection model. In vivo proteolytic degradation is due to proteolysis by several gut proteases such as trypsin, $\alpha$-chymotrypsin, pancreatic elastase, and pepsin. Protease treated yersiniae are shown to be less invasive in a cell culture model. YadA, another surface adhesin is cleaved by similar concentrations of gut proteases but Myf was not cleaved, showing that not all surface proteins are equally susceptible to degradation by gut proteases.

Conclusions: We demonstrate that gut proteases target important Yersinia virulence factors such as invasin and YadA in vivo. Since invasin is completely degraded within 2-3 h after reaching the small intestine of mice, it is no longer available to mediate invasion of Peyer's patches.
\end{abstract}

\section{Background}

Y. enterocolitica and $Y$. pseudotuberculosis cause foodborne gastrointestinal disease in humans. While Y. pseudotuberculosis is primarily an animal pathogen that only rarely causes disease in humans, $Y$. enterocolitica is one of the most common causes of gastroenteritis especially in northern Europe where $Y$. enterocolitica is the third most common cause of bacterial gastroenteritis [1]. Yersinia infection can manifest as enteritis, terminal ileitis, or mesenteric lymphadenitis (pseudoappendicitis) but can occasionally lead to septicaemia with abscess formation in liver and spleen in predisposed patients (e.g. iron overload). After several weeks, immunological sequelae such as reactive arthritis or erythema nodosum may complicate yersiniosis [1]. After oral uptake, yersiniae are known to invade Peyer's patches (PP) of the ileum by entering through specialized epithelial cells called $M$ cells. This is made possible by the interaction of the Yersinia invasin with $\beta 1$ integrins which are expressed on the luminal side of $\mathrm{M}$ cells but not enterocytes [2]. After translocation across the mucosal barrier, yersiniae

\footnotetext{
* Correspondence: truelzsch@mvp.uni-muenchen.de Max von Pettenkofer Institut für Hygiene und Medizinische Mikrobiologie, Ludwig Maximilians Universität München, Germany
}

subsequently disseminate to lymph nodes, spleen and liver where they form monoclonal microabscesses [3].

Invasin (Inv) is a chromosomally encoded outer membrane protein which is expressed at low temperature and early stationary phase, conditions which are prevalent in stored foods $[4,5]$. Invasin is anchored by its $\mathrm{N}$-terminal region in the outer membrane. In Y. pseudotuberculosis the $\mathrm{C}$-terminal end forms an 18 angstrom rod consisting of five globular domains (D1-D5) [6]. The C-terminal cell adhesion superdomain (D4 and D5) is the minimal region that is able to bind $\alpha \beta 1$ integrins $[7,8]$. High affinity binding by $Y$. pseudotuberculosis however also requires the D2 domain, which is absent in Y. enterocolitica. D2 mediates oligomerization of Inv on the bacterial surface which promotes the clustering of integrin receptors on host cell membrane generating a critical signal that leads to internalization of bacteria [9].

Another adhesin besides Inv, which is able to potentially interact with $\beta 1$ integrins of $M$ cells is the pYV plasmid encoded yadA, the prototype of a novel class of nonfimbrial adhesins (the oligomeric coiled coil adhesin family) $[10,11]$. YadA is a $41-44 \mathrm{kDa}$ surface protein that forms trimers in the outer membrane. These appear as $23 \mathrm{~nm}$ lollipop-shaped projections consisting of an $18 \mathrm{~nm}$ stalk and a $5 \mathrm{~nm}$ head [12]. YadA binds diverse 
extracellular matrix (ECM) proteins such as collagen, fibronectin and laminin $[13,14]$. Furthermore YadA mediates indirect binding of yersiniae to $\beta 1$ integrins through fibronectin- $\beta 1$ integrin bridging $[15,16]$. As is the case for the Inv- $\beta 1$ integrin interaction, the YadAfibronectin- $\beta 1$ integrin bridging leads to IL- 8 production and to internalization of yersiniae by Hep- 2 cells. These effects are however short lived and are weaker than for Inv [16]. YadA is a multifunctional protein [14] that is responsible not only for adhesion and bacterial autoagglutination but also protects yersiniae from the actions of defensins and confers resistance to serum complement lysis. Serum resistance is mediated by the stalk domain whereas adherence to neutrophils and collagen binding are mediated by the head region. A yadA knock out mutant was highly attenuated both after oral and i. v.- infection [17].

Invasin is the most important mediator of invasion into Peyer's patches in vivo but YadA and the attachment-invasion locus protein (Ail) which mediates attachment and invasion of eukaryotic cells in vitro are further candidates that might play a role in vivo $[18,19]$. The chromosomally encoded myf (mucoid Yersinia factor) is similar to the $\mathrm{pH} 6$ antigen of $Y$. pestis and is composed of $15 \mathrm{kDa}$ subunits that appear as a fibrillar layer surrounding bacteria. Myf enhances binding to cells and intestinal mucus [20]. We have recently discovered that only very few yersiniae of a large inoculum $\left(10^{9}\right)$ invade Peyer's patches from the gut lumen in the mouse infection model [3]. We are now exploring mechanisms that lead to this phenomenon. Since Inv, YadA, and Myf are exposed on the bacterial surface, they could be targets of gut proteases such as trypsin, $\alpha$-chymotrypsin, pancreatic elastase, carboxypeptidases or pepsin. In fact Inv has been shown to be cleaved by extracellular trypsin in vitro [21,22]. Proteolytic degradation of these proteins in the intestine would obviously limit contact of Yersinia with M cells of the distal ileum contributing to clonal invasion. Although it has been shown that pathogenic bacteria are targeted by stomach acid and defensins [23-26] in the GI tract, there are no reports of the effects of gut proteases on virulence factors of enteric pathogens.

\section{Methods}

\section{Bacterial strains and plasmids}

$Y$. enterocolitica WA-314 is a clinical isolate of serotype $\mathrm{O}: 8$ [27]. WA-C is a derivative of WA-314 [27] not harboring the pYV plasmid [3]. WA-C(pYV-kan) harbors a kanamycin cassette in a non-coding region of the $\mathrm{PYV}$ plasmid [3]. WA-C-inv and WA-314-inv are isogenic invasin mutants of WA-C and WA-314 respectively [28]. To construct a myfA mutant, a 645 bp $m y f$-fragment was subcloned and insertional inactivation of the $m y f A$ gene was accomplished by introducing a spectinomycin resistance cassette amplified from $\Omega$ plasmid into the internal KpnI restriction site of the myfA gene. The $m y f A:: s p e c$ construct was transferred to the suicide plasmid pEP185.2. This resulting mutator plasmid pEP185.2myfA::spec was mobilized into strain WA-314 by conjugation from $E$. coli S17-1 $\lambda$ pir, and the chromosomal $m y f A$ gene was replaced with the myfA::spec construct by double recombination. Allelic exchange was confirmed by PCR. Bacteria were cultured aerobically in Luria-Bertani (LB) broth or on LB agar plates at $27^{\circ} \mathrm{C}$. Antibiotics were used at the following concentrations $(\mu \mathrm{g} / \mathrm{ml})$; kanamycin: 25; chloramphenicol: 20 , tetracycline: 20.

\section{Oral mouse infection}

6-8 week old female Balb/c mice (Harlan-Winkelmann) were kept under specific pathogen-free-conditions (positive-pressure cabinet) and were provided with food and water ad libitum. Mice were infected orally with yersiniae grown to stationary phase in LB medium at $27^{\circ} \mathrm{C}$. Mice were sacrificed by $\mathrm{CO}_{2}$ asphyxiation and small intestines were aseptically removed. Bacteria were washed from the small intestines (SI) with PBS, and filtered with a $5 \mu \mathrm{m}$ Durapore filter (Millipore) to remove debris. The number of yersiniae in the lavage was determined by plating serial dilutions on CIN agar. The indicated number of yersiniae were subjected to SDS PAGE on $11.5 \%$ polyacrylamide gel (Figure 1 ). Immunoblotting was performed using nitrocellulose sheets. Blocking was performed with $5 \%$ BSA in PBS overnight at $4{ }^{\circ} \mathrm{C}$. Polyclonal rabbit anti-Inv antiserum recognizing the $4 \mathrm{C}$ terminal domains of $Y$. enterocolitica invasin and a horseradish-peroxidase-conjugated secondary anti-rabbit antibody were used for immunostaining. The rabbit $\alpha$ Inv antibody was raised against a recombinant protein containing the extracellular domains D1, D3, D4, and D5 (C-terminal 397 AA) of $Y$. enterocolitica WA-314. This region harbours the $\beta 1$ integrin binding site but not the membrane anchor. All mouse experiments were approved by government authorities (Regierung von Oberbayern, AZ 55.2-1-54-2531-153-07).

\section{Adhesion and Invasion assays}

$\mathrm{HeLa}$ cells were infected with yersiniae grown at $27^{\circ} \mathrm{C}$ at MOIs of 50 in 24 well plates. Yersiniae were centrifuged onto cells and incubated at $37^{\circ} \mathrm{C}$ for $90 \mathrm{~min}$. Extracellular yersiniae were killed by addition of gentamicin ( 50 $\mu \mathrm{g} / \mathrm{ml}$ ) for $1 \mathrm{~h}$. Cell lysis was performed with $0.1 \%$ triton/PBS. The number of intracellular and extracellular bacteria was determined by plating serial dilutions of bacteria on agar plates as described previously [29]. Adhesion assays were performed at $20^{\circ} \mathrm{C}$, invasion experiments at $37^{\circ} \mathrm{C}$. Results are expressed as percent 


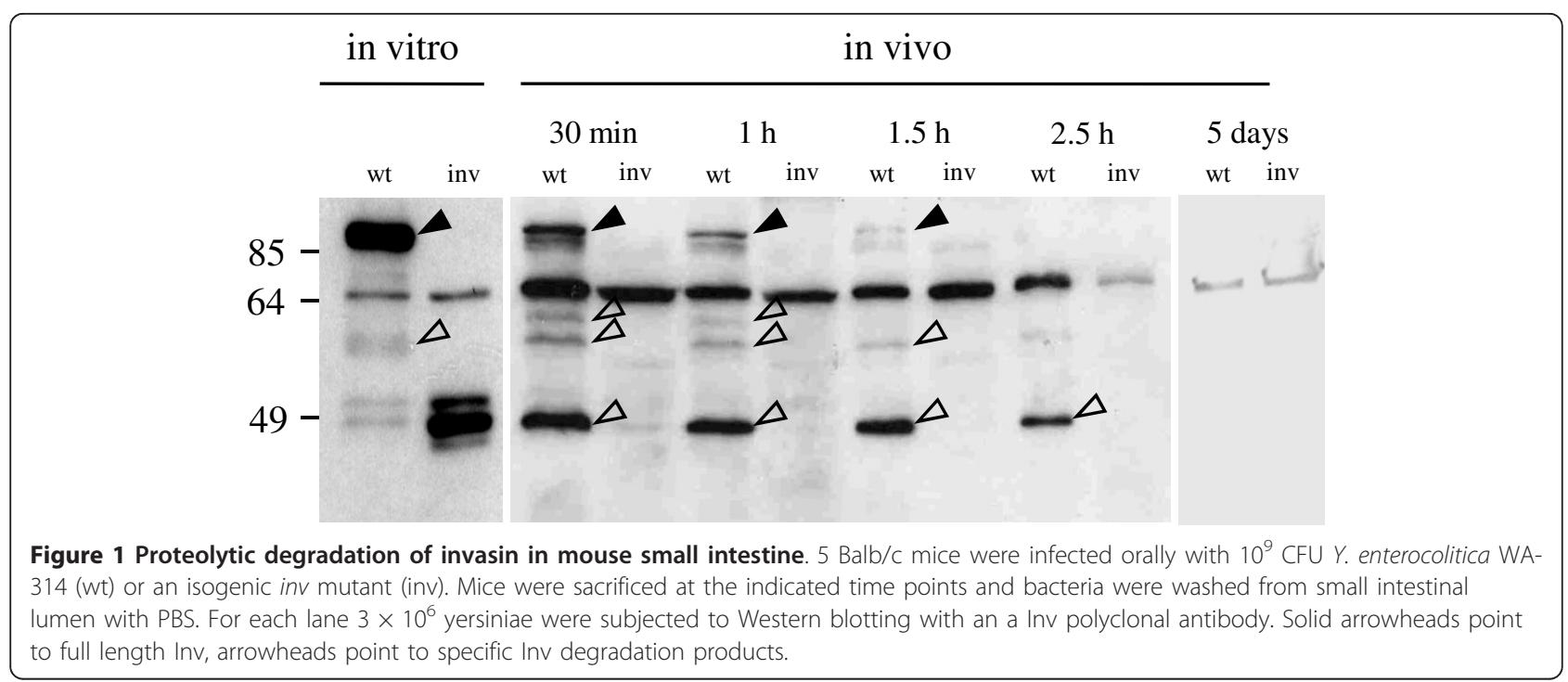

invasion $(100 \times \mathrm{CFU}$ of Yersinia resistant to gentamicin/ cell associated bacteria). Plating serial dilutions of protease treated yersiniae demonstrated viability of yersiniae after protease treatment. Bacteria treated with proteases were not found to be hypersensitive to the Triton detergent. Statistical analysis was performed using MannWhitney test at the 0.05 significance level.

\section{Protease digests}

Yersiniae in Figure 2 lanes 11 and 12 were digested with 2,5 $\mathrm{mg} / \mathrm{ml}$ trypsin in Tris-base $\mathrm{pH} 8.0,11.5 \mathrm{mM} \mathrm{CaCl}_{2}$. This is higher than concentrations of trypsin found in intestinal fluid of humans [30]. Yersiniae in Figure 3 were digested with undiluted human ileal fluid. Yersiniae in Figures 4, 5 and 6 were digested with trypsin $(23 \mu \mathrm{g} / \mathrm{ml}$ in Tris-base $\mathrm{pH} 8.0,11.5 \mathrm{mM} \mathrm{CaCl}$ ), $\alpha$-chymotrypsin $\left(20 \mu \mathrm{g} / \mathrm{ml}\right.$ in $100 \mathrm{mM}$ Tris/Cl pH 7.8, $\left.10 \mathrm{mM} \mathrm{CaCl}_{2}\right)$, pancreatic elastase $\left(10 \mu \mathrm{g} / \mathrm{ml} 100 \mathrm{mM} \mathrm{NH}_{4} \mathrm{HCO}_{3} \mathrm{pH}\right.$ 8.0) or carboxypeptidase A $(50 \mu \mathrm{g} / \mathrm{ml}$ in $25 \mathrm{mM}$ Tris $/ \mathrm{Cl}$ $\mathrm{pH}$ 7.65). These concentrations are below physiological values which have been reported to be about $280 \mu \mathrm{g} / \mathrm{g}$ feces, $450 \mu \mathrm{g} / \mathrm{g}$ feces, and $200 \mu \mathrm{g} / \mathrm{g}$ feces respectively [30]. The pepsin digest in Figure $4 \mathrm{a}(4 \mathrm{mg} / \mathrm{ml}$ in 10 $\mathrm{mM} \mathrm{HCl}$ ) was performed using a concentration slightly higher than that reported for human gastric juice of $0.5-1 \mathrm{mg} / \mathrm{ml}$ [31]. All proteases were obtained from Sigma-Aldrich.

$10^{7}$ yersiniae grown at $27^{\circ} \mathrm{C}$ in $\mathrm{LB}$ medium were washed with $\mathrm{PBS}$ and digested at $37^{\circ} \mathrm{C}$ or $27^{\circ} \mathrm{C}$ in the respective buffers. Following digestion for $1 \mathrm{~h}$ yersiniae were harvested by centrifugation and subjected to immunoblotting as described above. Yersiniae were also digested with small intestinal secretions of Balb/c mice. For this purpose, SI was washed with $3 \mathrm{ml} \mathrm{PBS}$,

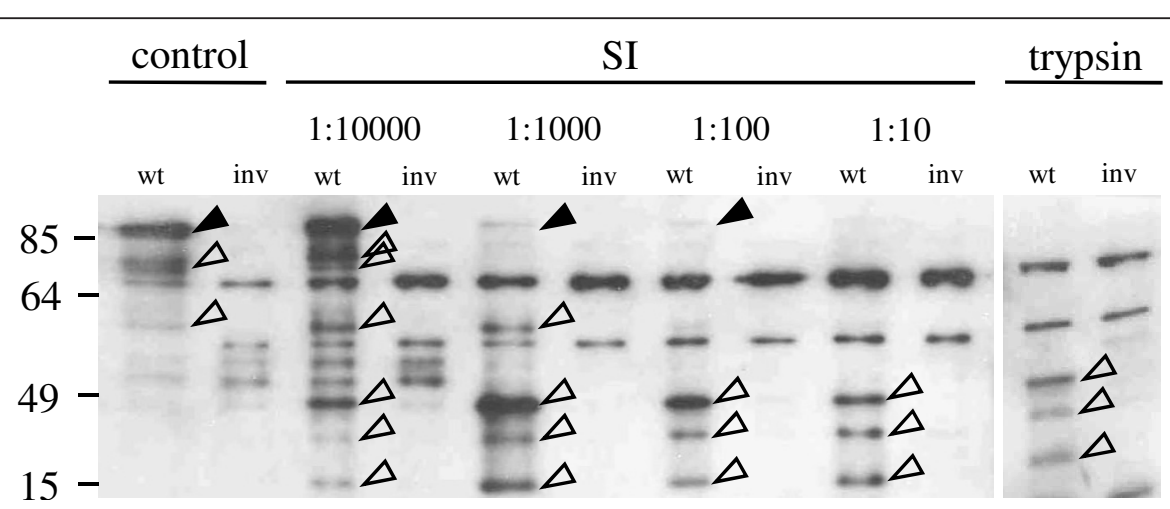

Figure 2 In vitro proteolytic degradation of invasin. Y. enterocolitica WA-314 (wt) or the invasin mutant (inv) were digested for $2 \mathrm{~h}$ at $37^{\circ} \mathrm{C}$ with small intestinal fluid of mice (SI) in different dilutions (1:10 - 1:10000). Digests with trypsin and trypsin digestion buffer (control) are also shown. The small intestines of mice were washed with $2 \mathrm{ml}$ trypsin digestion buffer, centrifuged, and the supernatant was used to digests $3 \times$ $10^{6} \mathrm{CFU}$ of yersiniae. Immunoblotting was performed with an a inv polyclonal antibody. Solid arrowheads point to full length Inv, open arrowheads point to specific Inv degradation products. 


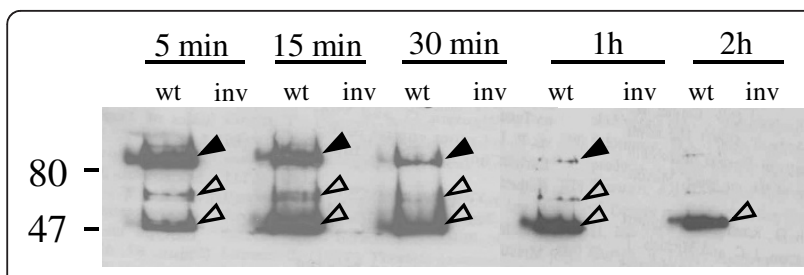

Figure 3 Kinetics of proteolysis by human ileal fluid. $10^{8} \mathrm{CFU} Y$. enterocolitica WA-314 (wt) or the invasin mutant (inv) were digested at $37^{\circ} \mathrm{C}$ for the indicated time with $1 \mathrm{ml}$ human ileal fluid. For each lane $3 \times 10^{6}$ yersiniae were subjected to Westerm blotting with an a Inv polyclonal AB. Solid arrowheads point to full length Inv, open arrowheads point to specific Inv degradation products.

centrifuged and the supernatant was used for digests. Protease inhibition was performed with $\alpha 1$ antitrypsin $(10 \mathrm{mg} / \mathrm{ml})$.

\section{Results}

\section{Inv is degraded in vivo by gut proteases}

To determine if the surface exposed Yersinia virulence factor invasin (Inv) is targeted by gut proteases in the mouse infection model, we orally infected groups of five

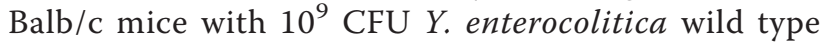
and an isogenic inv mutant. Bacteria were washed from the lumen of the small intestine after $30 \mathrm{~min}, 1 \mathrm{~h}, 1.5 \mathrm{~h}$, and $2.5 \mathrm{~h}$ post infection and were subjected to Western blotting using a polyclonal invasin antibody. As can be seen in Figure 1 the $92 \mathrm{kDa}$ full length Inv protein is rapidly degraded in vivo. Only $30 \mathrm{~min}$ after oral infection of mice a significant amount of invasin is degraded to a $49 \mathrm{kDa}$ protein with only this degradation product and no full length Inv remaining after $2.5 \mathrm{~h}$. Several larger partial degradation products (open arrowheads) can also bee seen in yersiniae cultured in vitro in the absence of protease treatment (lane 1 of Figure 1, 2, 3 and 4). This is a well known phenomenon that has been described previously $[21,22]$. To determine if Inv is subsequently produced in the gut lumen, we performed immunoblotting using the Inv antibody on yersiniae washed from the SI of mice that were infected for 5 days. We could not detect full length protein or degraded Inv by Western blotting (Figure 1). These

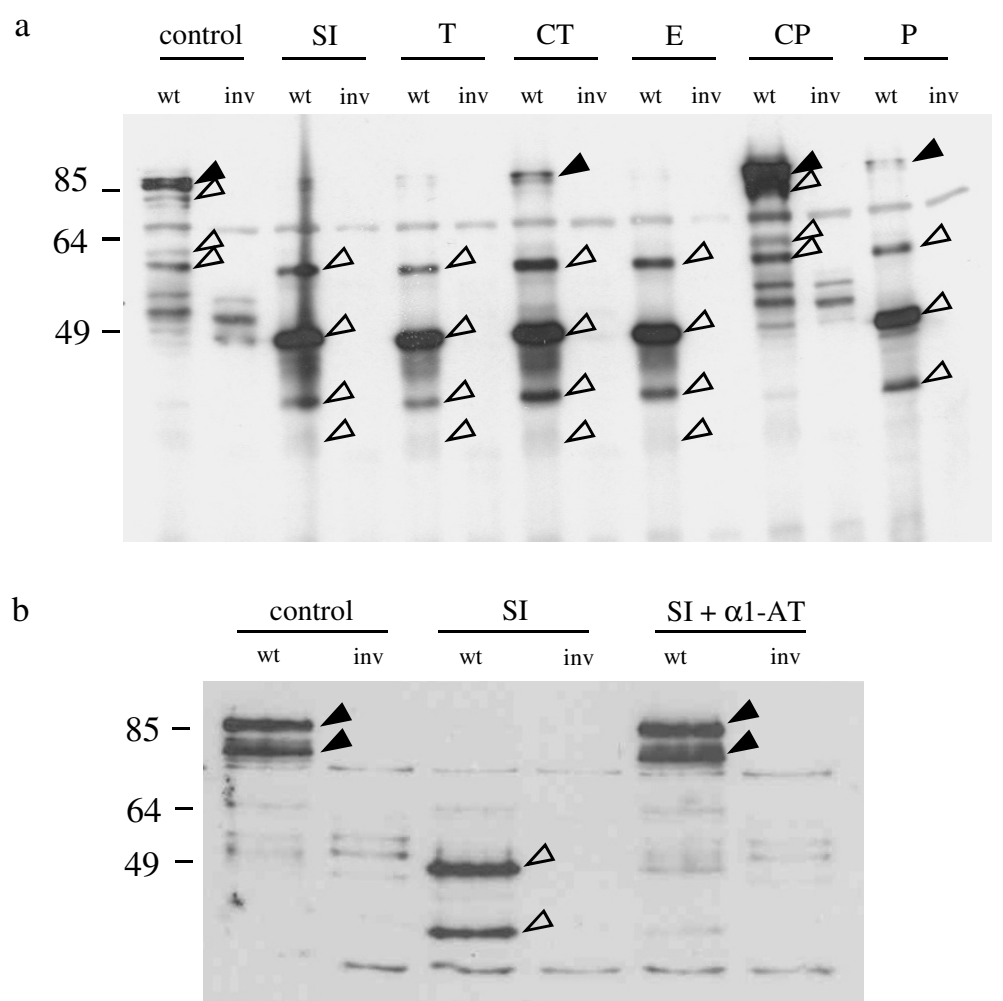

Figure 4 Serine proteases target invasin. (a) Wild-type $Y$. enterocolitica (wt) or the invasin mutant (inv) were digested with small intestinal fluid from mice (SI), $\alpha$-chymotrypsin (CT), trypsin (T), carboxypeptidase A (CP), pepsin (P), elastase (E) or trypsin digestion buffer (control) for $2 \mathrm{~h}$ at $37^{\circ} \mathrm{C}$. SI was washed with $2 \mathrm{ml} \mathrm{PBS}$, centrifuged, and supernatant was used for digests. $1 \times 10^{7} \mathrm{CFU}$ of yersiniae were subjected to Western blotting with an a inv polyclonal AB. (b) Y. enterocolitica WA-314 (wt) or the invasin mutant (inv) were digested with the supernatant of small intestinal luminal fluid (SI), mock digested with PBS or digested with SI preincubated with a1-antitrypsin for $1 \mathrm{~h}$ at $37^{\circ} \mathrm{C} .1 \times 10^{7} \mathrm{CFU}$ of yersiniae were subjected to Western blotting with an $\alpha$ inv polyclonal AB. Solid arrowheads point to full length Inv, open arrowheads point to specific Inv degradation products. 


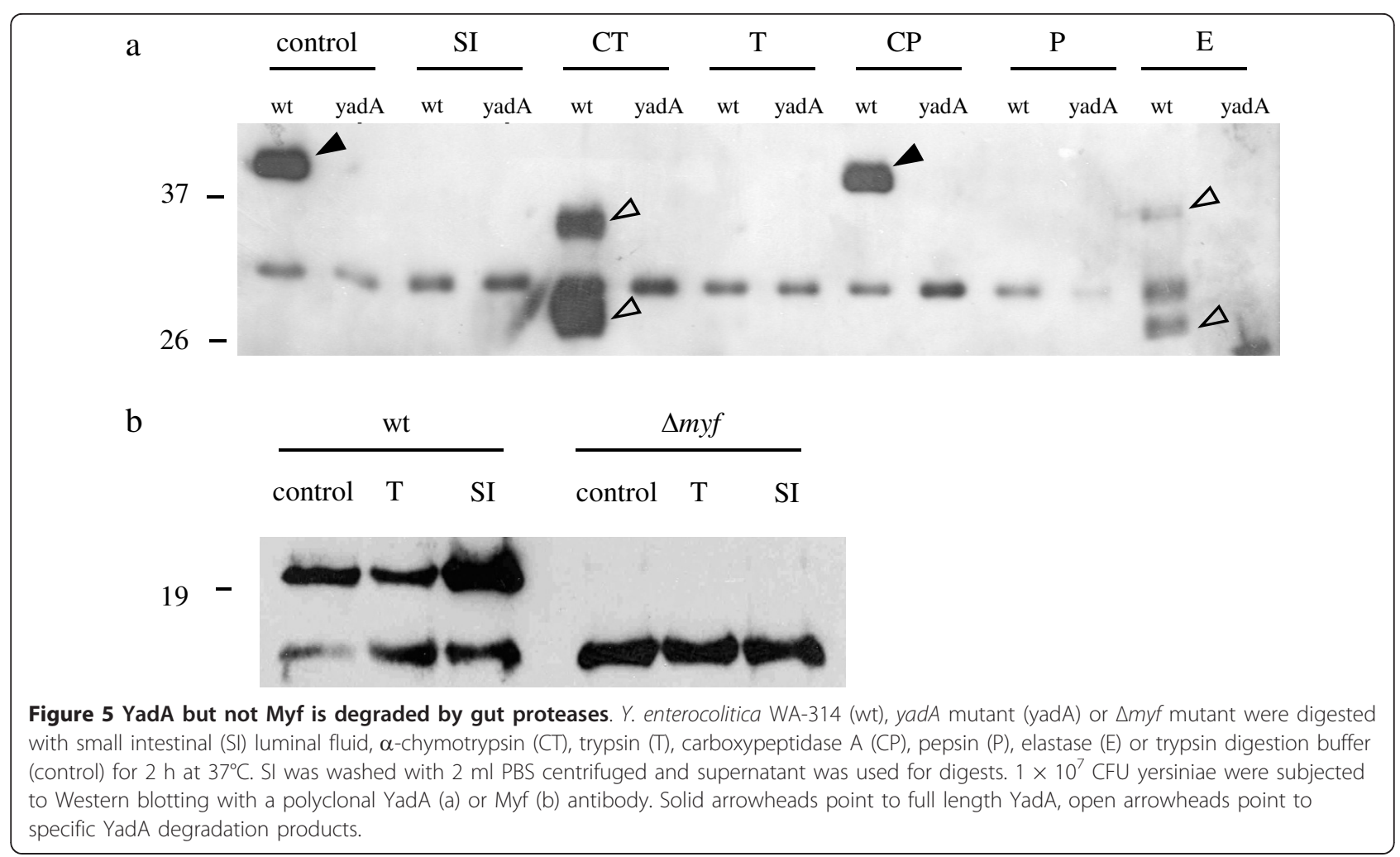

results indicate that the major invasion factor of Yersinia is degraded within a few hours after oral uptake by gut proteases and is subsequently not produced in the gut lumen at detectable levels. This presumably limits Inv mediated early invasion of PPs by Yersinia to a very short time window of a few hours only.

\section{Inv is cleaved in vitro into 3 peptides}

To determine if in vivo degradation could be reproduced in vitro, we digested wild-type yersiniae grown in LB medium at $27^{\circ} \mathrm{C}$ with serial dilutions (1:10-1:10000) of SI fluid and trypsin for $2 \mathrm{~h}$ at $37^{\circ} \mathrm{C}$ (Figure 2). As a control, digests were performed with the inv mutant. This experiment revealed that three distinct Inv degradation products were generated by in vitro digestion of yersiniae with either concentrated or a 1:10 dilution of SI luminal secretions. Complete digestion with a high trypsin concentration revealed an identical peptide pattern. Even when SI fluid was highly diluted (1:1000 1:10000), Inv was degraded but larger partial a

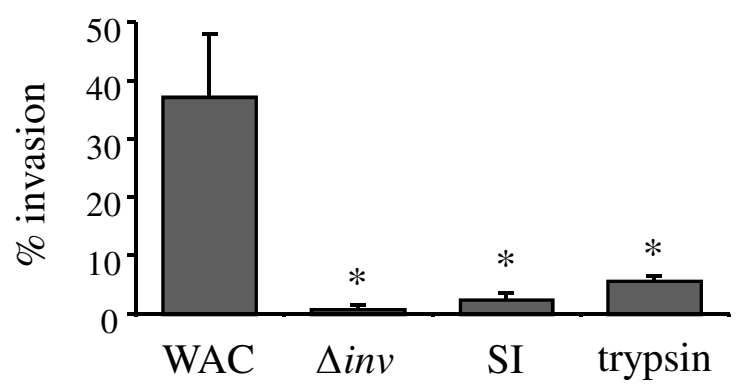

b

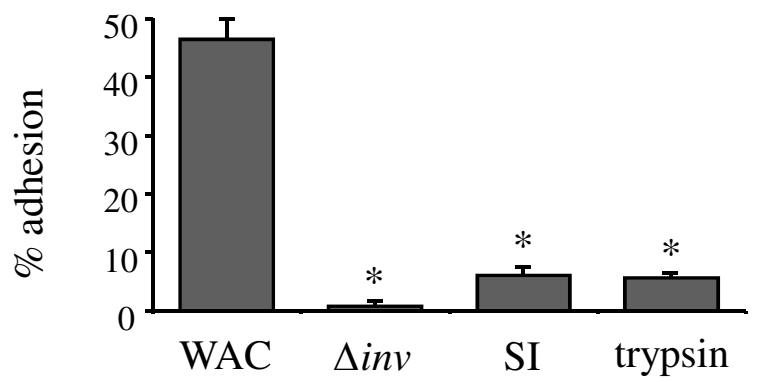

Figure 6 Gut protease treated yersiniae are less invasive in vitro. Y. enterocolitica WA-C or the invasin mutant WA-C-inv ( $\Delta$ inv) were digested with the supernatant of small intestinal luminal fluid (SI) or trypsin or mock digested with trypsin digestion buffer. Invasion (a) and adhesion (b) assays were performed using HeLa cells. Invasion assay was performed at $37^{\circ} \mathrm{C}$, adhesion assay at $20^{\circ} \mathrm{C}$. Percent yersiniae surviving gentamicin treatment is shown in (a), Percent yersiniae adhering to cells and SD is shown in (b). Statistical analysis was performed using Mann-Whitney test at the 0.05 significance level. Asteriks indicate a significant difference from WA-C. 
degradation products were also visible. This shows that Inv is highly susceptible to gut protease cleavage even at concentrations below physiological levels.

Interestingly several non-specific peptides (seen also for the inv mutant in Figure 2) were also degraded by gut proteases. To determine if the in vivo observed kinetics of digestion could be reproduced in vitro, undiluted human ileal secretions obtained by endoscopy from patients were used to digest yersiniae grown in LB medium. This experiment showed that full length Inv was degraded to a $49 \mathrm{kDa}$ peptide within about $2 \mathrm{~h}$ (Figure 3) as was the case in the in vivo mouse experiment.

\section{Serine proteases target invasion}

To identify gut proteases that might be responsible for the observed Inv degradation in vivo, we performed protease digests with in vitro grown yersiniae using trypsin, $\alpha$-chymotrypsin, pancreatic elastase, carboxypeptidase A and pepsin. For this purpose $10^{7}$ yersiniae were grown at $27^{\circ} \mathrm{C}$ in LB medium, washed with PBS and digested in their respective buffers for $2 \mathrm{~h}$. Yersiniae were harvested by centrifugation and subjected to immunoblotting with a polyclonal anti-Inv antiserum. In parallel yersiniae were digested with small intestinal secretions of Balb/c mice. These experiments showed that invasin is degraded to a major $49 \mathrm{kDa}$ peptide non-specifically by multiple proteases such as trypsin, $\alpha$-chymotrypsin, elastase, and pepsin, but not by carboxypeptidase A (Figure 4a). Digests with carboxypeptidase showed only 3 specific larger partial degradation products (ca. $60-80$ $\mathrm{kDa}$ ) that are also seen in the non digested control yersiniae. The slightly differing band pattern seen in Figure 4a vs. Figure 2 is due to incomplete digestion of the 55 kDa peptide seen in Figure 4. These partial digestion products can also be seen in lanes 3 and 5 of Figure 2 when highly diluted (1:1000 and 1:10000) SI secretions from mice were used for digests.

To determine if protease cleavage in the SI was due to serine proteases, digests of yersiniae with SI secretions were performed in the presence of $\alpha 1$ antitrypsin. These experiments showed that degradation of Inv by SI secretions could be inhibited by a serine protease inhibitor. As can be seen in Figure 4b, full length Inv and a slightly smaller spontaneous degradation product are completely digested to the 49 and $25 \mathrm{kDa}$ peptides only in the absence of protease inhibitor. To determine if there were differences in susceptibility to different proteases, digests were performed with trypsin, $\alpha$-chymotrypsin, and elastase at concentrations between $0.001 \mu \mathrm{M}-10 \mu \mathrm{M}$. This experiment revealed that Inv was most susceptible to trypsin cleavage being completely degraded in $1 \mathrm{~h}$ at a concentration of $0.1 \mu \mathrm{M}$ followed by $\alpha$-chymotrypsin and elastase which are completely degraded at a concentration of $1 \mu \mathrm{M}$ (results not shown).

\section{YadA but not Myf is degraded by gut proteases}

To determine if protease attack on Inv was a non-specific phenomenon, other surface proteins were studied by Western blotting after treating yersiniae with SI secretions or proteases (Figure 5). These experiments revealed that YadA is also cleaved quite non-specifically by several gut proteases such as trypsin $\alpha$-chymotrypsin, pepsin and elastase (but not carboxypeptidase A) at concentrations similar to those that cleave Inv. SI secretions from mice as well as trypsin and pepsin completely degraded YadA, whereas $\alpha$-chymotrypsin and elastase digests revealed 2 distinct degradation products (open arrowheads in Figure 5). In contrast to YadA and Inv however, Myf was not degraded by SI secretions or trypsin, demonstrating that not all surface proteins are degraded unspecifically in the gut.

\section{Protease treated yersiniae are less invasive in vitro}

To determine if gut protease attack on Yersinia is relevant for the infection process, we performed adhesion and invasion assays using HeLa cells. For these experiments yersiniae lacking the virulence plasmid pYV were digested with SI secretions or trypsin $(0.23 \mu \mathrm{g} / \mathrm{ml})$. Viability of yersiniae after protease treatment was not compromised and verified by plating serial dilutions of protease treated yersiniae. Tetracycline was added to inhibit protein synthesis during cell culture experiments (to inhibit new Inv expression). Yersiniae treated with protease digestion buffer were used as controls. These experiments revealed that yersiniae pre-treated with SI secretions or trypsin were much less invasive (similar to an inv mutant) than yersiniae treated with trypsin digestion buffer. Furthermore protease digested yersiniae were much less adherent to HeLa cells than control bacteria (Figure 6) as expected.

\section{Discussion}

While passing through the GI tract enteropathogenic bacteria are subjected to many adverse conditions such as the acidity of the stomach, antimicrobial peptides and gut proteases. The relevance of most of these factors in killing or inhibiting bacteria has been demonstrated $[23,24,32]$. However there are no reports of the effects of gut proteases on surface exposed virulence factors of enteric pathogens. We therefore studied the role of gut proteases on surface exposed virulence factors of Yersinia such as Inv, YadA, and Myf.

It has previously been demonstrated that only very few yersiniae invade Peyer's patches from the gut lumen resulting in the formation of very few monoclonal microabscesses $[3,33]$. The host has been shown to severely restrict the sequential invasion of Peyer's patches by yersiniae [3] which obviously contributes to the low number of yersiniae invading and abscessing 
PPs. But the low frequency with which Yersinia initially establishes abscesses in PPs cannot be explained by this mechanism. Since Inv is a surface located protein we postulated that Inv is attacked by gut proteases in the small intestine which would prevent interaction of yersiniae with $\beta$-integrins of $M$ cells. To investigate the fate of invasin at very early time-points after infection, we orally infected mice with $Y$. enterocolitica and analysed Inv production by Western blotting in the small intestines of mice. The $92 \mathrm{kDa}$ full length Inv protein of yersiniae grown at $27^{\circ} \mathrm{C}$ was still detectable in the small intestine shortly after oral infection but was rapidly degraded in vivo. Only $30 \mathrm{~min}$ after oral infection a significant amount of invasin was degraded to a ca. $49 \mathrm{kDa}$ protein with only this degradation product and no full length Inv remaining after $2.5 \mathrm{~h}$. As reported previously, Inv was not detectable in the SI lumen between 2 and 5 days after oral infection [3]. These results indicate that this major invasion factor of Yersinia is degraded within a few hours after oral uptake by gut proteases and is no longer available to mediate invasion of PPs. Of course other factors such as $\mathrm{pH}$, gut-microbiota and other gutenvironmental factors could also cause similar effects. Not surprisingly the invasion capacity of yersiniae for epithelial cells was greatly reduced when they were treated with trypsin or SI fluid prior to infection of HeLa cells. There is currently no suitable cell culture model to study invasion of M-cells in vitro and HeLa cells may not necessarily represent a suitable model for $\mathrm{M}$ cell invasion. Therefore it will be interesting to study the effects of gut proteases on the invasion of PPs in vivo. It is of course possible that in vivo yersiniae might be protected from the action of intestinal proteases in certain niches. They could for example be protected by intestinal mucus or might produce a biofilm in the gut. Possibly Inv could be protected from digestion by other Yersinia surface proteins such as YadA or Myf.

Proteolytic cleavage of Inv in vitro showed 3 distinct degradation products that were associated with yersiniae. We attempted to identify these degradation products in membrane preparations of Yersinia by MALDITOF but this was not possible since digested Inv peptides were not released into the supernatant and membrane preparations of Yersinia contained many proteins of similar size. We were, however, successful in identifying cleavage products by MALDI-TOF and protein sequencing using a recombinant protein consisting of 397 C terminal amino acids of Inv [34]. However, these peptides were distinct from those that were generated by digesting whole bacteria. Nevertheless, since the Inv antibody that we used is directed against domains D1D5 of Inv, the major degradation product of about 49 kDA that was observed in yersiniae washed from the SI of mice must represent the Inv membrane anchor with part of the D1 domain still intact.

Besides Inv we demonstrated that other surface proteins of Yersinia such as YadA are also readily degraded by gut proteases. However, protease attack on surface proteins does not seem to be a general phenomenon since MyfA which forms fibrillae on the Yersinia surface extending 2 microns [20] is not degraded by similar concentrations of trypsin or small intestinal fluid.

Gut proteases could have several effects on invasins and adhesins of bacteria. It is possible that such factors are activated by proteolysis. This has been shown for reovirus where luminal proteolytic digestion was important for rendering progeny virions infectious in the gut [35]. Alternatively, proteolysis of such adhesion factors might lead to inactivation and protect the host from hyperinvasion by Yersinia. Furthermore, proteolysis of invasins and adhesins could promote bacterial spreading to new hosts by increasing shedding of yersiniae in feces.

\section{Conclusions}

Yersinia virulence factors such as invasin are targeted by gut proteases in the lumen of the small intestine. Invasin, the most important invasion factor for Peyer's patches is rapidly degraded in the small intestine within 2-3 $\mathrm{h}$ after oral infection of mice and is therefore no longer available to mediate invasion of Peyer's patches. This is consistent with the finding that Yersinia invasion occurs very early during the infection process and might contribute to the low numbers of yersiniae reaching Peyer's patches after oral infection of mice.

\section{Acknowledgements}

This work was supported by DFG grant TR 740/2-1. We thank Ingo Autenrieth (Institut für Medizinische Mikrobiologie, Universität Tübingen) for anti-Inv polyclonal antibody for excellent technical assistance.

\section{Authors' contributions}

JT, MFO, KN, FE, KT performed experiments. KT conceived and designed the study. JT, and KT analyzed the data and wrote the manuscript. All authors approved the final manuscript.

\section{Competing interests}

The authors declare that they have no competing interests.

Received: 1 February 2011 Accepted: 18 April 2011

Published: 18 April 2011

\section{References}

1. Bottone EJ: Yersinia enterocolitica: the charisma continues. Clin Microbiol Rev 1997, 10:257-276.

2. Clark MA, Hirst BH, Jepson MA: M-cell surface beta1 integrin expression and invasin-mediated targeting of Yersinia pseudotuberculosis to mouse Peyer's patch M cells. Infect Immun 1998, 66:1237-1243.

3. Oellerich MF, Jacobi CA, Freund S, Niedung K, Bach A, Heesemann J, Trülzsch K: Yersinia enterocolitica infection of mice reveals clonal invasion and abscess formation. Infect Immun 2007, 75:3802-3811. 
4. Pepe JC, Badger JL, Miller VL: Growth phase and low pH affect the thermal regulation of the Yersinia enterocolitica inv gene. Mol Microbiol 1994, 11:123-135.

5. Isberg RR, Swain A, Falkow S: Analysis of expression and thermoregulation of the Yersinia pseudotuberculosis inv gene with hybrid proteins. Infect Immun 1988, 56:2133-2138.

6. Hamburger ZA, Brown MS, Isberg RR, Bjorkman PJ: Crystal structure of invasin: a bacterial integrin-binding protein. Science 1999, 286:291-295.

7. Leong JM, Fournier RS, Isberg RR: Identification of the integrin binding domain of the Yersinia pseudotuberculosis invasin protein. EMBO J 1990, 9:1979-1989.

8. Isberg RR, Leong JM: Multiple beta 1 chain integrins are receptors for invasin, a protein that promotes bacterial penetration into mammalian cells. Cell 1990, 60:861-871.

9. Dersch P, Isberg RR: A region of the Yersinia pseudotuberculosis invasin protein enhances integrin-mediated uptake into mammalian cells and promotes self-association. EMBO J 1999, 18:1199-1213.

10. Roggenkamp A, Ackermann N, Jacobi CA, Truelzsch K, Hoffmann H, Heesemann J: Molecular analysis of transport and oligomerization of the Yersinia enterocolitica adhesin YadA. J Bacteriol 2003, 185:3735-3744.

11. Barocchi MA, Masignani $V$, Rappuoli R: Opinion: Cell entry machines: a common theme in nature? Nat Rev Microbio/ 2005, 3:349-358.

12. Hoiczyk E, Roggenkamp A, Reichenbecher M, Lupas A, Heesemann J: Structure and sequence analysis of Yersinia YadA and Moraxella UspAs reveal a novel class of adhesins. EMBO J 2000, 19:5989-5999.

13. Nummelin H, Merckel MC, Leo JC, Lankinen H, Skurnik M, Goldman A: The Yersinia adhesin YadA collagen-binding domain structure is a novel lefthanded parallel beta-roll. EMBO J 2004, 23:701-711.

14. El Tahir Y, Skurnik M: YadA, the multifaceted Yersinia adhesin. Int J Med Microbiol 2001, 291:209-218.

15. Eitel J, Heise T, Thiesen U, Dersch P: Cell invasion and IL-8 production pathways initiated by YadA of Yersinia pseudotuberculosis require common signalling molecules (FAK, c-Src, Ras) and distinct cell factors. Cell Microbiol 2005, 7:63-77.

16. Hudson KJ, Bliska JB, Bouton AH: Distinct mechanisms of integrin binding by Yersinia pseudotuberculosis adhesins determine the phagocytic response of host macrophages. Cell Microbiol 2005, 7:1474-1489.

17. Roggenkamp A, Neuberger HR, Flugel A, Schmoll T, Heesemann J: Substitution of two histidine residues in YadA protein of Yersinia enterocolitica abrogates collagen binding, cell adherence and mouse virulence. Mol Microbiol 1995, 16:1207-1219.

18. Pepe JC, Wachtel MR, Wagar E, Miller VL: Pathogenesis of defined invasion mutants of Yersinia enterocolitica in a BALB/C mouse model of infection. Infect Immun 1995, 63:4837-4848.

19. Pepe JC, Miller VL: Yersinia enterocolitica invasin: a primary role in the initiation of infection. Proc Natl Acad Sci USA 1993, 90:6473-6477.

20. Iriarte M, Vanooteghem JC, Delor I, Diaz R, Knutton S, Cornelis GR: The Myf fibrillae of Yersinia enterocolitica. Mol Microbiol 1993, 9:507-520.

21. Young VB, Miller VL, Falkow S, Schoolnik GK: Sequence, localization and function of the invasin protein of Yersinia enterocolitica. Mol Microbiol 1990, 4:1119-1128.

22. Isberg RR, Voorhis DL, Falkow S: Identification of invasin: a protein that allows enteric bacteria to penetrate cultured mammalian cells. Cell 1987, 50:769-778.

23. Young GM, Amid D, Miller VL: A bifunctional urease enhances survival of pathogenic Yersinia enterocolitica and Morganella morganii at low $\mathrm{pH}$ 12. J Bacteriol 1996, 178:6487-6495.

24. Damasko C, Konietzny A, Kaspar H, Appel B, Dersch P, Strauch E: Studies of the efficacy of Enterocoliticin, a phage-tail like bacteriocin, as antimicrobial agent against Yersinia enterocolitica serotype $\mathrm{O} 3$ in a cell culture system and in mice 1. J Vet Med B Infect Dis Vet Public Health 2005, 52:171-179.

25. Tennant SM, Hartland EL, Phumoonna T, Lyras D, Rood Jl, RobinsBrowne RM, van DI: Influence of gastric acid on susceptibility to infection with ingested bacterial pathogens. Infect Immun 2008, 76:639-645.

26. de Koning-Ward TF, Robins-Browne RM: Contribution of urease to acid tolerance in Yersinia enterocolitica. Infect Immun 1995, 63:3790-3795.

27. Heesemann J, Laufs R: Construction of a mobilizable Yersinia enterocolitica virulence plasmid. J Bacteriol 1983, 155:761-767.
28. Ruckdeschel K, Roggenkamp A, Schubert S, Heesemann J: Differential contribution of Yersinia enterocolitica virulence factors to evasion of microbicidal action of neutrophils. Infect Immun 1996, 64:724-733.

29. Trülzsch K, Roggenkamp A, Aepfelbacher M, Wilharm G, Ruckdeschel K, Heesemann J: Analysis of chaperone-dependent Yop secretion/ translocation and effector function using a mini-virulence plasmid of Yersinia enterocolitica. Int J Med Microbiol 2003, 293:167-177.

30. DiMagno EP, Layer P: Human exocrine pancreatic enzyme secretion. In The Pancreas Biology, Pathobiology, and Disease. Edited by: Go VLW, DiMagno EP, Gardner JD, Lebenthal E, Reber HA, Scheele GA. New York: Raven; 1993:275-300.

31. Balan KK, Jones AT, Roberts NB, Pearson JP, Critchley M, Jenkins SA: The effects of Helicobacter pylori colonization on gastric function and the incidence of portal hypertensive gastropathy in patients with cirrhosis of the liver. Am J Gastroenterol 1996, 91:1400-1406.

32. de Koning-Ward TF, Robins-Browne RM: Contribution of urease to acid tolerance in Yersinia enterocolitica. Infect Immun 1995, 63:3790-3795.

33. Mecsas J, Bilis I, Falkow S: Identification of attenuated Yersinia pseudotuberculosis strains and characterization of an orogastric infection in BALB/C mice on day 5 postinfection by signature-tagged mutagenesis. Infect Immun 2001, 69:2779-2787.

34. Wiedemann A, Linder S, Grassl G, Albert M, Autenrieth I, Aepfelbacher M: Yersinia enterocolitica invasin triggers phagocytosis via beta1 integrins, CDC42Hs and WASp in macrophages. Cell Microbiol 2001, 3:693-702.

35. Bass DM, Bodkin D, Dambrauskas R, Trier JS, Fields BN, Wolf JL: Intraluminal proteolytic activation plays an important role in replication of type 1 reovirus in the intestines of neonatal mice. J Virol 1990, 64:1830-1833.

doi:10.1186/1756-0500-4-129

Cite this article as: Trček et al:: Gut proteases target Yersinia invasin in vivo. BMC Research Notes 2011 4:129.

\section{Submit your next manuscript to BioMed Central and take full advantage of:}

- Convenient online submission

- Thorough peer review

- No space constraints or color figure charges

- Immediate publication on acceptance

- Inclusion in PubMed, CAS, Scopus and Google Scholar

- Research which is freely available for redistribution

Submit your manuscript at www.biomedcentral.com/submit
C) Biomed Central 